\title{
Does the Next Generation of Sports Leaders Perceive the Presence of the Glass Ceiling and the Need to Shatter It? Insights of Undergraduate Students
}

\author{
Erika Gray \\ Western University \\ W. James Weese \\ Western University
}

The rungs for advancement up the corporate ladder in the sports industry can be slippery for women. Is the next generation of sports leaders aware of this fact? Senior undergraduate sport management students from Canadian universities completed the Career Pathways Survey (CPS) instrument to measure their perceptions of the glass ceiling. Both groups aspire to senior leadership roles. However, only the students who identified as women perceived the presence of a glass ceiling. Sport management students need to be better educated on the presence of the glass ceiling so the benefits of equitable, inclusive, and diverse leadership groups can be realized.

Keywords: sport leadership, women, student perceptions, barriers

\section{INTRODUCTION}

Women are enrolling in university undergraduate and graduate programs and also entering professional careers in greater numbers than at any other time in history (Statistics Canada, 2017). Sport management is one area of substantial growth in our institutions of higher learning, and students enrolled in these programs explicitly state that they aspire to careers in the field upon graduation (Forsyth et al., 2019; Hancock, et al., 2018; Harris et al., 2015).

As in other fields, higher percentages of women are also entering and graduating from these sport management programs (Simmons, 2011). By volume alone, it is logical to predict that a higher number of women sport management students will eventually serve in senior leadership positions in the sports industry. However, a review of the employment data would confirm that this is not the case (Acosta \& Carpenter, 2014; Burton, 2015; Burton \& Leberman, 2017; Hancock et al., 2018; Kamphoff, 2010; Lovett \& Lowry, 1994; Mazerolle et al., 2015; Shaw, 2006; Smith et al., 2012). These researchers and others have pointed to the institutional and social barriers like the glass ceiling, the glass cliff, the glass wall, homologous reproduction, role congruity theory, the "old boys' network", sexual harassment, discrimination, access and treatment discrimination, and stereotypes as some of the reasons for this slow pace of change. Government and organizational policies that trumpet equity, diversity, and inclusion have helped, but the situation does not appear to be changing in the sports industry at a reasonable pace (Burton \& Leberman, 2017; Hancock et al., 2018; Jones \& Palmer, 2011; Pfister \& Radtke, 2006). Another strategy might be needed. Perhaps greater attention needs to be focused on the next generation of sports leaders. 
The researchers of the current study undertook a descriptive research study to undercover the perceptions that men and women students studying sport management have regarding the barriers that women may face in advancing to senior leadership positions in the sports industry.

\section{Self-Inflicted Barriers and Perceptions}

According to Sartore and Cunningham (2007), women frequently do not attain top leadership positions in sport organizations due to self-limiting behaviors. Kay \& Shipman (2014) elaborated on this finding by noting that women have a greater tendency to minimize their accomplishments and sabotage their confidence, unlike their male counterparts. Some women counter these perceptions by feeling the need to further prove themselves to their colleagues by working longer hours and taking on more arduous assignments (Betzer-Tayar et al., 2017; Burton et al., 2012; Kilty, 2006; Norman, 2010; Norman \& RankinWright, 2018; Walker \& Bopp, 2010). Other researchers (Burton, 2015; Forsyth et al., 2019; Kay \& Shipman, 2014; Moreau \& Leathwood, 2006) have suggested that women frequently put limits on their advancement (e.g., not applying for senior leadership roles believing that they lack the qualifications) which also explain the discrepancy in representation in the executive suites. Women often underestimate their contributions and abilities, they often think that they lack the skills and ability to position and promote themselves relative to their men counterparts. As a result, women frequently leave middle management roles early due to a perceived lack of support, recognition, and respect (Burton \& Leberman, 2017; Aman et al., 2018). This is also described by other researchers (Aman et al., 2018; Hancock \& Hums, 2006; Helfat et al., 2006; Pell, 1996; Ragins et al., 1998; White, 2004) as the "leaky pipeline". Kay \& Shipman (2014) have proven that men will apply for jobs when they meet a minimal percent of the requirements, whereas women will only apply to the job when they meet all of the requirements. Burton (2015) found that women in the sports industry do not apply for, and/or secure mid-level leadership roles that would help them build their experience profile and better qualify them for more senior-level leadership roles in the industry. These practices further reduce the number of women in candidate pools for senior-level roles. Getting to these positions is a significant issue. How they are treated is another issue of significant consequence.

Women also report that they endure more criticism than men for their behaviors in the workplace (Ryan \& Haslam, 2005). Hancock et al. (2018) and Smith et al. (2012) suggest that many of the organizations' policies and practices value men's activities and contributions more than women's. These realities make workplace environments hostile, antagonistic, and discriminatory for women (Cunningham, 2008). Burton (2015) suggested that sports organizations often encourage male-dominated leadership while other researchers (Knoppers \& Anthonissen, 2007; Sartore \& Cunningham, 2007) suggest that inequitable power dynamics prevail in sport organizations that favor men. This cycle needs to break. However, it appears to be replicated in the selection process as well as in the day-to-day operations.

Fewer women working in the senior levels of leadership in the sports industry results in a loss of women role models, mentors, and sponsors that also contribute to the low participation rates at the senior leaders' levels of the industry. Women who have broken through the barriers and moved into senior leadership roles often point to these conditions (Burton et al., 2012; Cosentino et al., 2021; Kamphoff, 2010; Mazerolle et al., 2015; Mazerolle \& Eason, 2016).

\section{Gender Representation in Sport Leadership}

Sport is not the only industry with work to do in this critical area. Researchers continue to uncover the imbalance of senior women leaders in multiple sectors including, but not limited to, business and academia (Burton, 2019; Hideg \& Shen, 2019; Seo \& Huang, 2017). Although the number of women serving on executive boards has increased, proportional inequities still exist (Seierstad et al., 2017; Torchia et al., 2018). Reports issued by organizations like the Workplaces that Work for Women (2020) note that as of July of 2018, only $3.3 \%$ of women held Chief Executive Officer (CEO) positions in the companies on the Toronto Stock Exchange. In addition, only $30 \%$ of these companies had a woman as an executive officer. Various researchers have confirmed that there are a minimal number of women in leadership positions in business (Dean, 2016; Desvaux et al., 2007; Hartmann-Tews \& Pfister, 2005; Lyness \& Grotto, 2018; Sanchez \& Frey, 2019). The data for sports organizations reveal a similar trend. Men significantly 
outnumber women in a variety of roles such as athletic directors (Taylor \& Wells, 2017), as athletic trainers (Mazerolle et al., 2015), sports physicians (Stern et al., 2013), sports coaches or head coaches (Acosta \& Carpenter, 2014; Kane \& LaVoi, 2018; Reade et al., 2009; Walker \& Bopp, 2010), female sports academics (Whaley \& Krane, 2012), and executive roles within organized sport (Acosta \& Carpenter, 2014; Burton et al., 2011; Forsyth et al., 2019; Grappendorf \& Lough, 2006; Kane \& LaVoi, 2018; LaVoi \& Dutove, 2012). These statistics are concerning when coupled with the fact that more women are graduating from institutions of higher education programs where students are being prepared for careers in the industry (Statistics Canada, 2017).

In $2006,32.8 \%$ of women aged 25 to 34 held a bachelor's degree or higher, while $24.8 \%$ of men did (Statistics Canada, 2017); by 2016, this rose to $40.7 \%$ of women, and $29.1 \%$ of men (Statistics Canada, 2017). Furthermore, the same source reports that more women are holding doctoral degrees in fields like business, management, public administration, education, and health-related fields. It is clear that more women are graduating than men, but there is not a parallel transfer to the senior leadership ranks in a number of these sectors. Unfortunately, this same pattern is also played out in the sports industry where women are disproportionately underrepresented at senior leadership levels (Simmons, 2011). In fact, there is a "glacially slow progress toward the advancement of women into sport leadership" (Burton \& Leberman, 2017 , p. 16). As of 2018, women only held $2 \%$ of the positions on senior boards in sport organizations in Canada (Facts and Stats, n.d.). In addition, women only occupy $15 \%$ of the 98 senior leadership roles in Canadian-based Major League Soccer, Major League Baseball, the National Hockey League, the National Basketball Association, and the Canadian Football League. Something happens along women's career paths to perpetuates this imbalance.

Leading change in this area also makes sense on performance grounds. Researchers have demonstrated that the presence of women in leadership roles has been proven to have positive implications on an organization's performance. For example, scholars like Desvaux et al. (2007) determined that the presence of women in leadership roles correlates with better decision-making processes, more diverse perspectives to deliberations, a richer set of ideas, and many positive financial outcomes like increased return on equity, stock price growth, and operational savings. Hoobler et al. (2018) stated that having more women in leadership positions is good for business. Their meta-analysis indicated that having women in senior executive roles or as members of a Board of Directors generally leads to improved company performance (Hoobler et al., 2018). Researchers have also determined that when women sit on Boards of Directors they contribute to heightened levels of innovative thinking, heightened engagement, less negative conflict, and superior preparation for board meetings (Torchia et al., 2018). Furthermore, current thinking in leadership calls for advanced communication skills (Robinson et al., 2008; Yang et al., 2019), heightened levels of emotional intelligence (Ashkanasy \& Humphrey, 2011), and a higher ability to relate with one's experiences (Mayer et al., 2016). Researchers have confirmed that these skills are generally more prevalent in women (Lee \& Chelladurai, 2018; Zheng et al., 2018). Despite these findings and advances for change, women remain underrepresented in sport leadership.

Many organizations have attempted to address the inequity by implementing diversity programs and gender equity policies (Facts and Stats, n.d). For example, $47 \%$ of Canadian sport organizations, stated that they committed to implementing a gender equity policy to their governance documents by January of 2019. In addition, $17 \%$ of these sports organizations made the same commitment for their senior staff officers in their organizations (Facts and Stats, n.d). Affirmative action laws and government-imposed employment equity legislation have also been implemented. However, change has been very slow to transpire (Lough \& Grappendorf, 2007; Moore et al., 2001).

Homologous reproduction, defined as a tendency for those hiring "[...] to give employment to those who are the most similar to them, as a means of reducing organizational uncertainty" (Forsyth et al., 2019, p. 82). It may also be a contributing factor to understanding the underrepresentation of women in sport organizations. This is a structural barrier to women gaining entry to senior leadership roles and perpetuates a culture often described as the "old boys' club" (Forsyth et al., 2019; Shaw, 2006). Men tend to occupy the senior leadership roles in sport organizations (Acosta \& Carpenter, 2014; Kamphoff, 2010; Lovett \& Lowry, 1994; Mazerolle et al., 2015). Other barriers have been identified as a glass wall, glass ceiling, or 
glass cliff (Burton \& Leberman, 2017). The glass wall refers to the opportunities that women are provided with, in that there is a lack of access to working in sport (Burton \& Leberman, 2017). The glass ceiling refers to the lack of support that women receive to advance; in other words, there is an inability to progress in the organization (Burton \& Leberman, 2017). The glass cliff is characterized by a lack of support or consistency for women, resulting in higher risk and ultimately prompting failure when women are promoted to positions (Burton \& Leberman, 2017). Hancock et al. (2018) challenged the idea of the glass ceiling by stating that women experience a leadership labyrinth. They stated that while not every woman will hit a glass ceiling, many will encounter a leadership labyrinth in which they experience challenges that often limit their career advancement (Hancock et al., 2018).

Another structural barrier purported to limit women's advancement to leadership levels in sport organizations is the lack of women role models, mentors, and sponsors. These supports are critical to career advancement. As noted earlier, there is a small number of women employed in the senior levels of sports organizations. Younger women don't see many women in these roles and consequently may question whether there are opportunities for them (Block \& Tietjen-Smith, 2016). While men can play a mentoring and sponsorship role for other women, researchers (e.g., Block \& Tietjen-Smith, 2016; Kilty, 2006; Walker $\&$ Bopp, 2010) have confirmed that same-sex role models, mentors, and sponsors are most effective in increasing the confidence of women and undoubtedly their success in gaining more senior leadership roles in the industry (Burton et al., 2012; M'mbaha \& Chepyator-Thomson, 2018).

Bower and Hums' (2009) study of physical education departments confirmed the importance of mentoring to career advancement for women and especially for women and girls working with women mentors. They found that mentoring helped women overcome various barriers that prevented other women from advancing their careers in sport and physical education (Bower \& Hums, 2009). Women in senior positions considered mentoring other women a professional obligation. However, with a dearth of women in these roles, the opportunities for other women are severely limited and the problem is perpetuated. Other researchers (e.g., Aman et al., 2018; Burton, 2015; Shaw \& Frisby, 2006; Shaw \& Hoeber, 2003) have also highlighted the difficulties women often experience in networking within the sports industry as one of the challenges to significant advancement of women into senior leadership roles. Women do not have access to the same number of women peers, mentors, advocates, and sponsors (Darvin et al., 2019; Deane et al., 2015; Weiner \& Burton, 2016).

\section{Student Perceptions and Career Expectations}

Hancock et al. (2018) conducted a study of sport management students in the United States using the 38-item Career Pathways Survey (CPS) instrument and they confirmed that a complex number of barriers exist for women that impede their advancement to senior leadership levels, commonly referred to as the "glass ceiling". Students rated the perceived barriers of acceptance, denial, resilience, and resignation on a seven-point Likert-type scale. Key findings from this research were that: male students felt that barriers to advancement for women no longer existed and that women were less interested in seeking positions at high levels in sport. Both the male and female students felt that women overcome the glass ceiling barrier. The female students felt that women would not give up on their careers in the face of barriers or obstacles (Hancock et al., 2018). The researchers concluded that the career advancement for women may resemble more of a leadership labyrinth as opposed to a shattering of the glass ceiling (Hancock et al., 2018). It was noted that women in particular will experience barriers, but in different ways and at different points in time throughout their careers (Hancock et al., 2018). This recommendation was advanced based on the fact that women must navigate multiple barriers to advance in their careers in the industry (Hancock et al., 2018).

In a similar context, Harris et al. (2015) had used focus groups to determine perceptions of undergraduate female students. While the female students were excited about the career prospects of entering the sports industry they had concerns about job discrimination (i.e., gender stereotypes, and gender discrimination) and the realities of working in the sports industry (i.e., difficulty networking, job market

constraints, long work hours, low salary range, and multiple role conflict). Despite these concerns, excitement remained regarding entrance into the field. 
Vianden \& Gregg (2017) extended the literature by applying a diversity lens to analyze the privilege heterosexual white college men have within the sports industry. They utilized focus groups to determine the reflections that heterosexual white men had on their role to help women in the sports industry. Overall, participants felt that they had a role to play within the industry when discussing women in sport and hiring processes to make a change. Forsyth et al. (2019) also used focus groups to study the issue and concluded that role models for women are needed and that organizations should promote the success of women in sport and business. Forsyth et al. (2019) also recommended that the provision of childcare services, networking opportunities, and gender-neutral applications would be beneficial to address the gender imbalance in the sports industry.

Finally, Sauder et al. (2018) also utilized focus groups to gain the female sport management majors' perspectives on barriers and supports in the academic discipline of sport management. Four themes emerged from Saurder et al. (2018) otherness, roles and credibility, prior experiences, and people of influence. These findings illustrated the power sport management faculty have in shaping their academic classroom in sport management, and their ability to provide support for their female students.

These studies highlight the need for undergraduate and graduate students to be aware of, and perceptive to, the barriers that women frequently face as they endeavor to advance their careers in the sports industry. To date, there has not been any research on this topic conducted with men and women sport management students in Canada. These students are the next generation of sport leaders in the country. This study addresses this need, and the results will help academic leaders better prepare students to navigate their careers and lead needed change in the sports industry.

\section{THEORETICAL FRAMEWORK}

This study was based on the glass ceiling research literature base. The glass ceiling is a metaphor that is commonly used in research when referring to the barriers and obstacles that women commonly face when they are seeking promotions in the top levels of organizations (Burke \& Vinnicombe, 2005; McLeod, 2008; Smith et al., 2012). This concept was introduced in 1986 in the Wall Street Journal as one of the major barriers to women advancing to leadership positions (Weyer, 2007). Due to the glass ceiling, women receive a lack of support when seeking to advance and this creates a lack of progression for women in the organization (Burton \& Leberman, 2017).

\section{METHODS}

This descriptive study was designed to explore and describe perceptions that men and women undergraduate students have about the barriers women may face in advancing their careers to the senior leadership levels within the sports industry. The study was approved in advance by the Western Universities Research Ethics Review Board before initiating the data collection process.

\section{Research Questions}

Two research questions guided this research project. These questions were:

1. Do men and women senior undergraduate students studying sport management have different career expectations for a senior leadership career in sport?

2. Do men and women senior undergraduate students studying sport management have perceptual differences regarding the barriers that women may face in advancing in sport to senior leadership roles?

\section{Study Population}

This study was conducted at nine universities that offer a sport management program in Canada according to the North American Society for Sport Management (NASSM) website. A total of 966 senior undergraduate students enrolled in a sport management class at the time of data collection were identified 
as qualified to participate in the study. To avoid frame error, students listed in two or more sport management classes were instructed to complete one survey form.

\section{Instrumentation}

The researchers adopted the methods from Hancock et al. (2018) which was a study that was conducted in the United States (U.S.). The researchers were granted permission to use the Career Pathways Survey (CPS) by Smith et al. (2012); a valid and reliable instrument specifically designed to measure the perceptions that respondents have about the barriers that might exist to impede career progression for women, as a result of the glass ceiling. The 38-item survey instrument produced interval data on a sevenpoint Likert type scale (i.e., $1=$ "strongly agree" through $7=$ "strongly disagree"). The instrument was designed to measure differences across four glass ceiling phenomena (i.e., resignation, acceptance, resilience, and denial). Two of the factors (denial and acceptance) have a reverse coding mechanism built into the scale to detect response set errors that threaten the validity of the data.

Denial is a measure of the belief that both men and women will have the same experiences when seeking leadership positions; in other words, the glass ceiling no longer exists (Smith et al., 2012). Ten of the 38-items in the Career Pathways Survey measured denial, and the internal consistency of this scale was previously computed as $\propto=0.81$ (Smith et al., 2012). Acceptance is a measure of women being content with not seeking careers in senior leadership (Hancock et al., 2018). Seven of the 38 -items in the Career Pathways Survey made up the acceptance scale. Smith et al. (2012) determined that the internal consistency of this scale was $\propto=0.72$. Resilience refers to a measure of a woman's desire to overcome the barriers that they face. In the context of this study, they persevere to secure a senior leadership position in sport. Eleven of the 38-items in the Career Pathways Survey measured resilience. Smith et al. (2012) calculated the internal consistency of the resilience measure to be $\propto=0.70$. Resignation is a measure of the perception that women give up or fail to achieve promotions because of social barriers (i.e., role congruity theory) or organizational obstacles (i.e., sexual discrimination, harassment). Ten of the 38-items in the Career Pathways Survey measured resignation and Smith et al. (2012) determined that the internal consistency of the resignation scale was $\propto=0.71$.

Each of the four scales of the Career Pathways Survey instrument exceeded the threshold of $\propto=0.70$ that Santos (1999) established as critical. Therefore, the scales were considered internally consistent.

\section{Data Collection Procedures}

The quantitative data from the undergraduate students studying sport management was collected using the Qualtrics program; an online platform that is ideal for conducting survey research. This approach was chosen due to the fact that professors needed to quickly distribute the survey forms to students given the immediate campus closings and shift to an online program delivery due to the impact of the COVID-19 virus. The professors at the nine universities distributed a survey link to their undergraduate students enrolled in senior sport management classes at their institution. The survey link along with the letter of information, the consent letter, and the purpose of the study was outlined in the opening section of the survey form. A context slide was then provided for the students which included head and shoulders pictures, job titles, and men and women in senior leadership within Professional/Major League sports organizations in Canada. The images represented the presidents and vice-presidents of Professional/Major League sports teams and leagues that operate in Canada. The images were also presented in the exact proportion to the percentage of men and women in senior leadership roles at the time of data collection. A caption accompanied the image that explained the slide and signaled the ratio of men and women presidents and vice-presidents in professional/major league sport in Canada (i.e., 85:15). Students were required to confirm that they had read the slide in advance of the data collection procedures. If students answered no to this question they were eliminated from the study. A two-step non-response procedure was enacted to maximize participation rates. A reminder email was distributed to the students one week after the initial distribution of the questionnaires. After four weeks the site was closed, and the data were uploaded to an excel spreadsheet to facilitate the analysis. 


\section{Data Analysis Procedures}

The quantitative data produced in this study were analyzed using the Statistical Package for Social Sciences 26 (SPSS). A chi-square analysis was computed to determine if there was a statistically significant difference between career aspirations of men and women students. A chi-square test was chosen due to two dichotomous items being cross-tabulated with another (i.e., "yes to senior leadership" versus "no to senior leadership" and these results were cross-tabulated with gender "men or women"). The analysis was undertaken following the guidance of Tabachnick et al. (2007). This generated a 2 x 2 matrix where the chi-square analysis was used to evaluate the observed or expected values in this matrix to determine if there was a statistical difference (Tabachnick et al., 2007). Computed values were compared to critical values at the $95 \%$ confidence interval level. Adjusted residuals were also calculated to confirm statistical significance. Finally, the phi coefficient association was calculated to determine the strength between the variables.

Descriptive statistics were computed using the data produced by the quantitative instrument. The four factors (i.e., acceptance, denial, resilience, and resignation) served as the dependent variables in the study. Means and standard deviations were calculated for each of the variables. A MANOVA was computed to determine if a significant difference existed between gender, specifically the perceptions that men and women students had regarding the barriers women face to advance. The MANOVA was selected as a result of having multiple dependent variables (Tabachnick et al., 2007). Computed F ratios were compared to the critical $\mathrm{F}$ ratios at a $95 \%$ confidence interval level. Wilk's Lambda post hoc analyses were not computed to determine precise areas of disparity since there were only two independent groups and it was apparent which group was larger. When calculating the means for each student, for each factor of the CPS, missing data were filled in using SPSS's function for missing data to provide the best estimation for these values.

\section{RESULTS}

One hundred eighteen surveys were collected for a $12 \%$ response rate. Ninety-three of the 118 surveys were completed in their entirety and therefore usable $(n=93)$ in the study. Of the 93 surveys, 41 students identified as women, and 52 students identified as men. Fifty-six percent of the women indicated that they aspired to senior leadership positions in sport, while $67 \%$ of the men indicated that they were looking to achieve senior leadership positions in sport. Twenty-nine students identified as being third-year students, 54 students identified as being fourth-year students, and ten students identified as being fifth-year and above students. The students ranged in age from 20 years of age to 34 years of age. Eighty-four percent of the respondents were between the ages of 21 and 24 years of age.

The researchers also computed the psychometric properties of the CPS instrument. Cronbach Alphas were computed for each of the four factors to determine the internal consistency values of the four scales. The results from this analysis are in harmony with the results that Smith et al. (2012) produced when the instrument was created. All but the resignation variable exceeded the threshold of 0.70 that Santos (1999) established as a threshold value. The internal consistency measures for the data collected in this study appear in Table 1.

\section{TABLE 1 \\ INTERNAL CONSISTENCY MEASURES OF THE CAREER PATHWAYS SURVEY INSTRUMENT}

\begin{tabular}{ll}
\hline Factor & Cronbach Alpha \\
\hline Denial & 0.84 \\
\hline Acceptance & 0.77 \\
\hline Resilience & 0.71 \\
\hline Resignation & 0.69 \\
\hline
\end{tabular}


The computed chi-square statistic $\left(\chi^{2}(1)=1.23, p=0.27\right)$ indicated that no significant difference exists between the men and women students relative to their aspirations to secure senior leadership positions. Additionally, the association (phi coefficient) between the variables is 0.12 which confirmed no relationship between the gender and senior leadership variable. The results confirmed that both men and women sport management students aspire to these roles with equal career ambition.

A multivariate analysis of variance (MANOVA) was also computed on the quantitative data produced by the CPS instrument. This statistical treatment was appropriate given the interval data produced by the instrument and the multivariate nature of the second research question. The computations were carried out using the SPSS program.

The gender variable had two levels (men versus women) and was evaluated as the independent variable in this analysis across the four dependent factors produced by the CPS instrument (i.e., denial, acceptance, resilience, and resignation). Descriptive statistics were initially computed for the dependent variables and they are presented in Table 2.

TABLE 2

DESCRIPTIVE STATISTICS FOR THE CAREERS PATHWAYS SURVEY MEASURES

\begin{tabular}{|c|c|c|c|c|c|c|}
\hline & $\begin{array}{l}\text { Men } \\
(n=52)\end{array}$ & & & $\begin{array}{l}\text { Women } \\
(n=41)\end{array}$ & & \\
\hline CPS Factor & Mean & $\begin{array}{l}\text { Standard } \\
\text { Deviation }\end{array}$ & $\begin{array}{l}95 \% \\
\text { Confidence } \\
\text { Interval }\end{array}$ & Mean & $\begin{array}{l}\text { Standard } \\
\text { Deviation }\end{array}$ & $\begin{array}{l}95 \% \\
\text { Confidence } \\
\text { Interval }\end{array}$ \\
\hline Denial & 4.22 & 0.70 & $(3.97,4.47)$ & 5.16 & 1.02 & $(4.88,5.44)$ \\
\hline Acceptance & 4.90 & 0.90 & $(4.67,5.13)$ & 5.55 & 0.75 & $(5.29,5.81)$ \\
\hline Resilience & 2.37 & 0.56 & $(2.22,2.52)$ & 2.20 & 0.52 & $(2.04,2.37)$ \\
\hline Resignation & 3.97 & 0.74 & $(3.77,4.16)$ & 3.96 & 0.64 & $(3.75,4.18)$ \\
\hline
\end{tabular}

The results of the MANOVA uncovered a significant difference (at the $95 \%$ confidence interval) between the men and women students on the overall CPS measure. A Pillai's Trace measure of $F(4,88)=8.287, p<0.001, \eta^{2}=0.27$ illustrated the difference.

Univariate comparisons were computed to identify the precise source of the differences between the men and women respondents. The statistically significant multivariate effect indicates a "protected F' and allows researchers to interpret the univariate effects without adjusting the per-comparison alpha. It was determined that gender differences did exist on the denial factor $\left(F(1,91)=25.09, p<0.001, \eta^{2}=0.22\right)$ with women $(M=5.16, S D=1.02)$ feeling much stronger about its presence than men $(M=4.22, S D=0.70)$. The men and women respondents also significantly differed on acceptance $\left(F(1,91)=13.71, p<0.001, \eta^{2}\right.$ $=0.13)$ with women $(M=5.55, S D=0.75)$ feeling more strongly that women do not accept the employment realities than men respondents $(M=4.9, S D=0.90)$. No significant differences were found on the resilience, $F(1,91)=2.23, p=0.139, \eta^{2}=0.02$ or resignation, $F(1,91)=0.000, p=0.988, \eta^{2}=0.000$ factors.

\section{DISCUSSION}

The study was guided by two research questions. The results for the first research question determined that both men and women students studying sport management had similar aspirations for senior leadership roles in sport. Both groups desired senior leadership roles and were therefore committed to attaining them. However, as noted earlier in this manuscript and throughout the women in sport leadership literature base, 
women are not reaching the senior leadership ranks in sport proportionate to the enrolment levels in undergraduate programs. Something happens along a career path that perpetuates an imbalance. For example, despite higher enrolment levels and roughly equal representation in our undergraduate sport management programs, as of 2018, women only held $2 \%$ of positions on boards in Canadian sport organizations (Facts and Stats, n.d.). Additionally, only 15\% of the vice-president and president positions in Major League/Professional Sport in Canada were occupied by women. Researchers (e.g., Acosta \& Carpenter, 2014; Burton, 2015; Burton \& Leberman, 2017; Hancock et al., 2018; Kamphoff, 2010; Lovett \& Lowry, 1994; Mazerolle et al., 2015; Shaw, 2006; Smith et al., 2012) have pointed to structural barriers like the glass ceiling, the glass cliff, the glass wall, and a host of other factors that continue to contribute to the low percentage of women in leadership positions in senior leadership in sport. Is the next generation of students cognizant of the glass ceiling, and if so, might they be the change agents who can address the inequity?

The second research question was used to determine if men and women undergraduate students studying sport management have similar perceptions about the barriers that women may face in advancing to senior leadership roles in the industry, and if these perceptions differ across the four factors of the glass ceiling (i.e., denial, acceptance, resilience, and resignation). The researchers uncovered a significant difference between the men and women students on the overall CPS measure. The women students had stronger feelings about the existence of the glass ceiling and perceive women will face the glass ceiling in their career advancement. The men students did not believe that the glass ceiling existed. A closer look revealed that significant differences were nested on two factors, namely denial, and acceptance. Perhaps the men students denied the existence of a glass ceiling because they do not experience it in the same way as their women counterparts. The women students may have been more cognizant of the concept due to their first-hand experience with barriers to advancement in youth sport, leadership opportunities in educational, community settings, or experiences with siblings.

The same might be said for the area of acceptance. If men students do not experience the glass ceiling, they may not feel the need to acknowledge the fact that women experience this barrier. Conversely, the women students may experience this in several campus, community, and familial settings, and are more accepting of the fact that the phenomenon exists. They are aware of the glass ceiling concept and accept the fact that it is an unfortunate reality for pursuing senior leadership roles in a male-dominated industry like sport.

No statistical difference was uncovered between the men and women undergraduate students in the areas of resilience and resignation. This may be due to the experiences that both groups have had in their lives. Students drawn to sport management programs typically have a sports background that may have tested their abilities and developed their resilience. They have often experienced "failure" and learned how to improve to overcome barriers that are placed in front of them. The men students may have watched their women colleagues face this type of leadership in their undergraduate programs, and therefore, have every confidence that they will overcome any barrier placed in front of them based on this observation. The women students may feel the same way based on their experiences in the classroom and community. This aligns with current literature that states that women know that they will likely face barriers to senior leadership advancement as they advance in the sports industry, but they pursue it nonetheless (Burton \& Leberman, 2017; Hancock et al., 2018; Jones \& Palmer, 2011; Pfister \& Radtke, 2006). Their confidence levels and experiences to date might suggest that at this point in their lives they believe that when they enter senior leadership positions they will persevere and overcome these barriers, and thus, attributing this perception to other women facing the barriers. Perhaps they feel that women will just work harder to get ahead (Burton, 2015; Burton \& Leberman, 2017; Hancock et al., 2018; Jones \& Palmer, 2011; Pfister \& Radtke, 2006). The men students likely see this kind of behavior in their classes and other campus and community, and familial settings. It could be possible that the men students have other women role models with this kind of resilience in their lives (e.g., mothers, sisters, grandmothers, and friends) who remain persistent in the face of adversity and have overcome challenges in life. Therefore, they believe that their women classmates are resilient and will overcome any career-limiting obstacle(s). 
The Hancock et al. (2018) research that was conducted in the United States produced similar and also conflicting results to the current study. The students in the current study seemed to have greater knowledge of the existence of the glass ceiling, specifically with the women students. This may be a function of time given the plethora of women and sport leadership research that has recently been published. Therefore, perhaps students of the current study are more aware of the realities of the glass ceiling in 2021 due to the more recent literature that has been published on the topic (Burton, 2019; Forsyth, et al, 2019; Hancock et al., 2018; Kane \& LaVoi, 2018), which is likely being presented to students in classroom settings and assignments. In addition, the Hancock et al. (2018) research was conducted in the United States while the current study was set in Canada. It is also possible that the cultural and political differences are in play mainly due to the presence of Title IX. Perhaps, as a result of Title IX students in the Hancock et al. (2018) study perceive a glass ceiling to be no longer existent. However, they may not be aware of the effect that Title IX has had on sexual discrimination, budget allocation, decreased women in sport business, neglect on assessing gender equity for women - which are all barriers that perpetuate the glass ceiling (Staurowsky, 2019).

The increased attention given across the literature bases might be effectively working its way into the Canadian university curricula. This could be attributed to the exceptional advocacy work of organizations like Canadian Women \& Sport and The Sport Information Resource Centre: SIRC (SIRC) that may be heightening awareness. Perhaps students in Canada are becoming even more aware as a result of these organizations' initiatives. Perhaps Canadian sport management professors are effectively integrating the materials of these organizations into their curricula, and in doing so, providing students with an understanding of the glass ceiling and its implications.

The men and women students who participated in the Hancock et al. (2018) study believed that women may be content with not seeking high leadership positions. The findings of this study were different. Both men and women students indicated a strong desire to secure a senior leadership position in the field upon graduation. Students in the Hancock et al. (2018) study believed that the glass ceiling barriers no longer existed, and the difference in proportional representation might be related to the fact that women were not seeking high-level leadership positions. The results of the current study were different. Once again, the passage of time might be a factor. The recent work uncovered and disseminated by scholars like Burton (2019), Forsyth, et al (2019; Hancock et al. (2018), and Kane and LaVoi (2018) amongst others may be getting through to students. The increased attention that this area has received of late may have prompted professors to spend more time discussing the concepts of equity, equality, diversity, and inclusion with students.

However, the results of both investigations suggest that there is still work to do in educating students who identify as men on the concept of the glass ceiling and the need to ensure more diverse and equitable workplaces. There is still a need to understand the prevalence of the glass ceiling in sport and we need to be open and committed to breaking the cycle and making positive change.

\section{IMPLICATIONS FOR SPORT MANAGEMENT AND SPORT LEADERSHIP}

The researchers of the current study focused on undergraduate students studying sport management. The results indicated that both men and women aspire to senior leadership roles in the industry. However, data suggest that women are vastly underrepresented in these ranks. Several researchers (Acosta \& Carpenter, 2014; Burton et al., 2011; Forsyth et al., 2019; Kane \& LaVoi, 2018; LaVoi \& Dutove, 2012) have analyzed the reasons from the perspectives of professionals already in the industry. This research contributes to a much smaller research base (e.g., Forsyth et al., 2019; Hancock et al., 2018) and focused on the perceptions and aspirations of students as they were preparing for careers in the industry.

Men and women sport management students both aspire to senior leadership positions upon graduation in equal proportions. These students need to know about the prevalence of the glass ceiling in the industry and graduate committed to making change. Diversity and equity are critically important. Vianden \& Gregg (2017) have strongly encouraged academics to weave diversity awareness and benefits into the curricula in sport management undergraduate and graduate programs. The researchers of the current study believe that 
the infusion of diversity starts with awareness, and professors can be helpful by presenting the research literature on the glass ceiling and the suggestions for breaking the cycle. As noted in this manuscript, it is not only right and fair, but it makes great business sense. Also noted in Gerzema and D'Antonio's (2013) book entitled The Athena Doctrine: How Women (and Men Who Act Like Them) Will Rule the World," [...] feminine values are ascendant. Powered by cooperation, communication, nurturing, and inclusiveness, among others, institutions, businesses, and individuals are breaking away from old masculine structures and mindsets to become more flexible, collaborative, and caring" (p. 255). The world is changing and the preferred style of leadership is more aligned with the traditional values and behavior patterns of women. Women sport management students should be inspired and empowered by that reality, and they will be if they know about this line of research.

The results brought light to the fact that men students are supportive of their women counterparts reaching the top senior leadership levels in the industry, however, they are less aware of the barriers that women will likely face on this journey. These students will require more empirical information on the prevalence of the glass ceiling and a greater understanding of how to help women overcome these barriers. Men can be important allies for change in the sports industry. This won't be done without inspiring responsibility that men, and especially white men, have in naming the privilege that they hold (Vianden \& Gregg, 2017). Higher education may be able to change this during these formative years. Professors and mentors may also be able to influence future leaders to uphold and celebrate the presence and benefits of equality, equity, diversity, and inclusion in the workplace. This is illustrated in the findings of Sauder et al. (2018) when they described the influence higher education has in supporting women students and encouraging inclusiveness in their classrooms. In addition to being fair and just, these principles make sense from the perspective of heightening organizational effectiveness (Desvaux et al., 2007; Torchia et al., 2018).

To make the change, Sperandio and Kagoda (2008) suggested that an emphasis needs to be placed on social justice for equality. The researchers of this study believe that change should also be motivated by performance aspirations. However, to create a change in the gender inequality that is evident in the sports industry, support needs to be provided from and for all parties involved. Students are not the only group that needs to be challenged to think outside of their comfort zones when learning about these barriers. Their professors also need to be inspired to produce necessary change. This can be accomplished by ensuring that their students are exposed to diverse and inclusive images and case studies and that these future leaders understand the legalities and benefits of a diverse and inclusive workforce. Bring women who are in senior sports leadership positions into the classroom as guest speakers so they can inspire students and serve as role models. Have these women share their experiences and the conditions that facilitated success for them. It would also be powerful to bring in presenters who identify as men and have a demonstrated record of promoting women to leadership roles in the sports industry. Have these senior leaders discuss their commitment to equity and the corresponding success their organization has realized as a result. Educators can ensure that men and women students understand the issues so they become advocates for change. Additionally, implement case studies that highlight the issue and the positive benefits accrued by being more diverse, inclusive, and equitable. Students need to understand the concept of the glass ceiling and how it plays out in the sports industry. Most of all, they need to know why it is important so they can aid in breaking the cycle. A lack of awareness of the barriers women face in the sports industry at the preparation level will undoubtedly lead to a lack of awareness that will continue to perpetuate inequality and inequity in the sports industry.

The results of this study also have important implications for both women students and women in the industry. While the results indicated that women have the requisite resilience to barriers, something does change along a woman's career path. Women frequently leave sports organizations at mid-career levels and therefore, are not available or eligible for more senior-level roles in the sports industry. White (2004) labeled this phenomenon as the "leaky pipeline". Scholars who have studied this, (e.g., Aman et al., 2018; Helfat et al., 2006; Pell, 1996; Ragins et al., 1998; White, 2004) suggest that women often leave organizations at a mid-career stage (e.g., due to personal priorities, and lack of social support). As a result, the pipeline that delivers qualified candidates for senior leadership roles, especially in sport is often devoid of women (Hancock \& Hums, 2016). Human resource policies must become more flexible and supportive 
to women. A more inclusive, encouraging workplace culture is also imperative to alter this unfortunate trend in sport organizations.

\section{CONCLUSION}

The results of this research confirm that men and women undergraduate students in Canadian universities studying sport management have similar aspirations for senior leadership roles in the field upon graduation. However, they have different perceptions about the barriers that women face as they attempt to advance into these senior leadership roles. The researchers believe that the academy could do more to better prepare students to understand the issues, and in the future, be more inclusive leaders.

The results of this study, coupled with the results of other studies in this area can help students better understand what might lie ahead of them, and allow them to adopt strategies to effectively navigate their way to the senior leadership levels in the industry. The results could also inform the teaching and mentorship strategies of professors who are committed to helping their students realize their career ambitions. Professors in sport management can better prepare their students to advance in their careers in sport leadership by increasing their awareness of the barriers that impede advancement, and especially how they impact the advancement of women. Finally, the results may help current and future leaders in the industry ensure that their human resource policies and workplace cultures support and facilitate the principles of equality, equity, diversity, and inclusion.

\section{REFERENCES}

Acosta, R.V., \& Carpenter, L.J. (2014). Women in intercollegiate sport: A longitudinal study-thirtyseven-year update. Retrieved from http://www.acostacarpenter.org/

Aman, M.P., Yusof, A., Ismail, M., \& Razali, A.B.M. (2018). Pipeline problem: Factors influencing the underrepresentation of women in the top leadership positions of sport organizations. Malaysian Journal of Movement, Health and Exercise, 7(2), 151-166. Retrieved from http://dspace.unimap.edu.my:80/xmlui/handle/123456789/55908

Ashkanasy, N.M., \& Humphrey, R.H. (2011). Current emotion research in organizational behavior. Emotion Review, 3(2), 214-224. https://doi.org/10.1177/1754073910391684

Betzer-Tayar, M., Zach, S., Galily, Y., \& Henry, I. (2017). Barriers to women's access to decision-making positions in sport organizations: The case of establishing a girls' volleyball academy in Israel. Journal of Gender Studies, 26(4), 418-431. https://doi.org/10.1080/09589236.2015.1111835

Block, B.A., \& Tietjen-Smith, T. (2016). The case for women mentoring women. Quest, 68(3), 306-315. https://doi:10.1080/00336297.2016.1190285

Bower, G.G., \& Hums, M.A. (2009). Mentoring women to advance within leadership positions as international physical educators. Women in Sport and Physical Activity Journal, 18(2), 3-13. https://doi:10.1123/wspaj.18.2.3

Burke, R., \& Vinnicombe, S. (2005). Advancing women's career. Career Development International, 10(3), 165-167. https://doi.org/10.1108/13620430510732012

Burton, L.J. (2015). Underrepresentation of women in sport leadership: A review of research. Sport Management Review, 18(2), 155-165. https://doi:10.1016/j.smr.2014.02.004

Burton, L.J. (2019). Under-representation of women in leadership roles in women's sport. In N. Lough \& A.N. Geurin (Eds.), Routledge Handbook of the Business of Women's Sport (pp. 255-268). Routledge.

Burton, L.J., \& Leberman, S. (2017). Women in sport leadership: Research and Practice for Change. Routledge.

Burton, L.J., Borland, J., \& Mazerolle, S.M. (2012). "They cannot seem to get past the gender issue": Experiences of young female athletic trainers in NCAA Division I intercollegiate athletics. Sport Management Review, 15(3), 304-317. https://doi:10.1016/j.smr.2012.01.001 
Burton, L.J., Grappendorf, H., \& Henderson, A. (2011). Perceptions of gender in athletic administration: Utilizing role congruity to examine (potential) prejudice against women. Journal of Sport Management, 25(1), 36-45. https://doi:10.1123/jsm.25.1.36

Canadian Women \& Sport. (n.d.). Retrieved May 7, 2021, from https://www.womenandsport.ca

Cosentino, A., Weese, J., \& Wells, J. (2021) Strategies to advance women: Career insights from senior leadership women in professional sport in Canada. Frontiers in Sport and Active Living, 3, 1-13. https://doi.org/10.3389/fspor.2021.716505

Cunningham, G.B. (2008). Creating and sustaining gender diversity in sport organizations. Sex Roles, 58(1), 136-145. https://doi:10.1007/s11199-007-9312-3

Davin, L., Taylor, E., \& Wells, J. (2019). Get in the game through a sponsor: Initial career ambitions of former women assistant coaches. Journal of Issues in Intercollegiate Athletics, 12, 590-613.

Dean, T. (2016). Double bind: Women of color in business leadership [Doctoral dissertation, Baylor University]. Retrieved from http://hdl.handle.net/2104/9883

Deane, C., Morin, R., Parker, K., Menasce Horowitz, Wang, W., Patten, E., \& Brown, A. (2015, January 14). Women and leadership: Public says women are equally qualified, but barriers persist. PEW Research Centre Report. Retrieved from http://www.pewsocialtrends.org/2015/01/14/womenand-leadership/

Desvaux, G., Devillard-Hoellinger, S., \& Baumgarten, P. (2007). Women matter: Gender diversity, a corporate performance driver. McKinsey \& Company.

Facts and Stats. (n.d.). Retrieved from https:/www.caaws.ca/women-on-boards/facts-and-stats/

Forsyth, J.J., Jones, J., Duval, L., \& Bambridge, A. (2019). Opportunities and barriers that females face for study and employment in sport. Journal of Hospitality, Leisure, Sport \& Tourism Education, 24, 80-89. https://doi.org/10.1016/j.jhlste.2019.01.005

Gerzema, J., \& D'Antonio, M. (2013) The Athena Doctrine: How women (and men who act like them) will rule the world. Jossey-Bass.

Grappendorf, H., \& Lough, N. (2006). An endangered species: Characteristics and perspectives from female NCAA Division I athletic directors of both separate and merged athletic departments. The Sport Management and Related Topics Journal, 2(3), 6-20.

Hancock, M.G., \& Hums, M.A. (2016). A "leaky pipeline"?: Factors affecting the career development of senior-level female administrators in NCAA Division I athletic departments. Sport Management Review, 19(2), 198-210. https://doi:10.1016/j.smr.2015.04.004

Hancock, M.G., Darvin, L., \& Walker, N.A. (2018). Beyond the Glass Ceiling: Sport Management Students' Perceptions of the Leadership Labyrinth. Sport Management Education Journal, 12(2), 100-109. https://doi.org/10.1123/smej.2017-0039

Harris, K.F., Grappendorf, H., Aicher, T., \& Veraldo, C. (2015). "Discrimination? Low pay? Long hours? I am still excited:" Female sport management students' perceptions of barriers toward a future career in sport. Advancing Women in Leadership, 35, 12-21. https://doi.org/10.18738/awl.v35i0.128

Hartmann-Tews, I., \& Pfister, G. (2005). Sport and women: Social issues in international perspective. Routledge. https://doi.org/10.4324/9780203987087

Helfat, C.E., Harris, D., \& Wolfson, P.J. (2006). The pipeline to the top: Women and men in top executive ranks of U.S. corporations. The Academy of Management Perspectives, 20(4), 42-64. https://doi.org/10.5465/amp.2006.23270306

Hideg, I., \& Shen, W. (2019). Why Still so Few? A theoretical model of the role of benevolent sexism and career support in the continued underrepresentation of women in leadership positions. Journal of Leadership \& Organizational Studies, 26(3), 287-303. https://doi.org/10.1177/1548051819489006

Hoobler, J.M., Masterson, C.R., Nkomo, S.M., \& Michel, E.J. (2018). The business case for women leaders: Meta-analysis, research critique, and path forward. Journal of Management, 44(6), 24732499. https://doi:10.1177/0149206316628643 
Jones, S.J., \& Palmer, E.M. (2011). Glass ceilings and catlights: Career barriers for professional women in academia. Advancing Women in Leadership, 31, 189-198. https://doi.org/10.18738/awl.v31i0.78

Kamphoff, C.S. (2010). Bargaining with patriarchy: Former female coaches' experiences and their decision to leave collegiate coaching. Research Quarterly for Exercise \& Sport, 81(3), 360-372. https://doi.org/10.1080/02701367.2010.10599684

Kane, M.J., \& LaVoi, N. (2018). An examination of intercollegiate athletic directors' attributions regarding the underrepresentation of female coaches in women's sports. Women in Sport \& Physical Activity Journal, 27(2), 110-117. https://doi.org/10.1123/wspaj.2018-0059

Kay, K., \& Shipman, C. (2014). The confidence code: The science and art of self what women should know. HarperCollins Publishers Inc.

Khattab, H.J., Shemla, M., \& Paluch, R.M. (2018). A multi-level process model for understanding diversity practice effectiveness. Academy of Management Annals, 12(1), 37-82. https://doi.org/10.5465/annals.2016.0044

Kilty, K. (2006). Women in coaching. The Sport Psychologist, 20(2), 222-234. https://doi.org/10.1123/tsp.20.2.222

Knoppers, A. (1992). Explaining male dominance and sex segregation in coaching: Three approaches. Quest, 44(2), 210-227. https://doi.org/10.1080/00336297.1992.10484051

Knoppers, A., \& Anthonissen, A. (2007). Gendered managerial discourses in sport organizations: Multiplicity and complexity. Sex Roles, 58(1), 93-103. https://10.1007/s11199-007-9324-z

LaVoi, N.M., \& Dutove, J.K. (2012). Barriers and supports for female coaches: An ecological model. Sport Coach Review, 1(1), 17-37. https://doi.org/10.1080/21640629.2012.695891

Lee, Y.H., \& Chelladurai, P. (2018). Emotional intelligence, emotional labor, coach burnout, job satisfaction, and turnover intention in sport leadership. European Sport Management Quarterly, 18(4), 393-412. https://doi.org/10.1080/16184742.2017.1406971

Lough, N.L., \& Grappendorf, H. (2007). Senior woman administrator's perspectives on professional advancement. International Journal of Sport Management, 8(2), 193-209.

Lovett, D.J., \& Lowry, C.D. (1994). "Good old boys" and "good old girls" clubs: Myth or reality? Journal of Sport Management, 8(1), 27-35. https://doi.org/10.1123/jsm.8.1.27

Lyness, K.S., \& Grotto, A.R. (2018). Women and leadership in the United States: Are we closing the gender gap? Annual Review of Organizational Psychology and Organizational Behavior, 5(1), 227-265. https://doi:10.1146/annurev-orgpsych-032117-104739

M'mbaha, J.M., \& Chepyator-Thomson, J.R. (2018). Factors influencing career paths and progress of Kenyan women in sport leadership. Qualitative Research Sport Exercise Health, 11(3), 316-333. https://doi.org/10.1080/2159676X.2018.1446042

Mayer, J.D., Caruso, D.R., \& Salovey, P. (2016). The ability model of emotional intelligence: Principles and updates. Emotion Review, 8(4), 290-300. https://doi.org/10.1177/1754073916639667

Mazerolle, S.M., \& Eason, C.M. (2016). Positive factors influencing the advancement of women to the role of head athletic trainer in the national collegiate athletic association divisions II and III. Journal of Athletic Training, 51(7), 550-556. https://doi:10.4085/1062-6050-51.9.03

Mazerolle, S.M., Burton, L., \& Cotrufo, R.J. (2015). The experiences of female athletic trainers in the role of the head athletic trainer. Journal of Athletic Training, 50(1), 71-81. https://doi.org/10.4085/1062-6050-49.3.50

McLeod, F. (2008). Glass ceiling still firmly in place. Retrieved from http://www.theaustralian.news.com.au/story/0,25197,23926883-30537,00.html

Moore, M.E., Parkhouse, B.L., \& Konrad, A.M. (2001). Women in sport management: Advancing the representation through HRM structures. Women in Management Review, 16(2), 51-61. https://doi.org/10.1108/09649420110386584

Moreau, M.P., \& Leathwood, C. (2006). Graduates' employment and the discourse of employability: A critical analysis. Journal of Education and Work, 19(4), 305-324.

https://doi.org/10.1080/13639080600867083 
NASSM. (n.d.). Retrieved from https://www.nassm.com/Programs/AcademicPrograms/Canada

Norman, L. (2010). Feeling second-best: Elite women coaches' experiences. Sociology of Sport Journal, 27(1), 89-104. https://doi.org/10.1123/ssj.27.1.89

Norman, L., \& Rankin-Wright, A. (2018). Surviving rather than thriving: Understanding the experiences of women coaches using a theory of gendered social well-being. International Review for the Sociology of Sport, 53, 424-450. https://doi.org/10.1177/1012690216660283

Pell, A. (1996). Fixing the leaky pipeline: Women scientists in academia. Journal of Animal Science, 74(11), 2843-2848. https://doi.org/10.2527/1996.74112843x

Pfister, G., \& Radtke, S. (2006). Dropping out: Why male and female leaders in German sports federations break off their careers. Sport Management Review, 9(2), 111-139. https://doi:10.1016/S1441-3523(06)70022-5

Ragins, B.R., Bickley Townsend, B., \& Mattis, M. (1998). Gender gap in the executive suite: CEOs and female executives report on breaking the glass ceiling. The Academy of Management Executive, 12(1), 28-42. https://doi.org/10.5465/ame.1998.254976

Reade, I., Rodgers, W., \& Norman, L. (2009). The under-representation of women in coaching: A comparison of male and female Canadian coaches at low and high levels of coaching.

International Journal of Sports Science \& Coaching, 4(4), 505-520. https://doi.org/10.1260/174795409790291439

Robinson, V.M., Lloyd, C.A., \& Rowe, K.J. (2008). The impact of leadership on student outcomes: An analysis of the differential effects of leadership types. Educational Administration Quarterly, 44(5), 635-674. https://doi.org/10.1177/0013161X08321509

Ryan, M.K., \& Haslam, S.A. (2005). The glass cliff: Evidence that women are over-represented in precarious leadership positions. British Journal of Management, 16(2), 81-90. https://doi:10.1111/j.1467-8551.2005. 00433.x

Sanchez, D.V., \& Frey, E.F. (2019). Where do females rise to leadership positions? A cross-sector analysis. Applied Economics Letters, 27(15), 1252-1255. https://doi.org/10.1080/13504851.2019.1676385

Santos, J.R.A. (1999). Cronbach's alpha: A tool for assessing the reliability of scales. Journal of Extension, 37(2), 1-5.

Sartore, M.L., \& Cunningham, G.B. (2007). Explaining the under-representation of women in leadership positions of sport organizations: A symbolic interactionist perspective. Quest, 59(2), 244-265. https://doi:10.1080/00336297.2007.10483551

Sauder, M.H., Mudrick, M., \& DeLuca, J.R. (2018, October). Perceived Barriers and Sources of Support for Undergraduate Female Students' Persistence in the Sport Management Major. Sport Management Education Journal, 12(2), 69-79. https://doi.org/10.1123/smej.2017-0025

Seierstad, C., Warner-Søderholm, G., Torchia, M., \& Huse, M. (2017). Increasing the number of women on boards: The role of actors and processes. Journal of Business Ethics, 141(2), 289-315. https://10.1007/s10551-015-27150

Seo, G., \& Huang, W.H.D. (2017). Social perceptions, gender roles, and female leadership: A theoretical grounding for understanding the underrepresentation of women in top-level management. In Encyclopedia of strategic leadership and management (pp. 619-630). IGI Global.

Shaw, S. (2006). Scratching the back of Mr. X: Analyzing gendered social processes in sport organizations. Journal of Sport Management, 20(4), 510-534. https://doi.org/10.1123/jsm.20.4.510

Shaw, S., \& Frisby, W. (2006). Can gender equity be more equitable? Promoting an alternative frame for sport management research, education, and practice. Journal of Sport Management, 20(4), 483509. https://doi.org/10.1123/jsm.20.4.483

Shaw, S., \& Hoeber, L. (2003). A strong man is direct and a direct woman is a bitch: Gendered discourses and their influence on employment roles in sports organizations. Journal of Sport Management, 17(4), 367-386. https://doi.org/10.1123/jsm.17.4.347 
Simmons, K. (2011). Women in top management positions in the sport industry: Breaking down the barriers and stereotypes. [Unpublished undergraduate thesis]. St. John Fisher College.

Smith, P., Crittenden, N., \& Caputi, P. (2012). Measuring women's beliefs about glass ceilings: Development of the Career Pathways Survey. Gender in Management: An International Journal, 27(2), 68-80. https://doi.org/10.1108/17542411211214130

Sperandio, J., \& Kagoda, A. M. (2008). Advancing women into educational leadership in developing countries: The case of Uganda. Advancing Women in Leadership, 27. Retrieved from https://search.proquest.com/openview/51884d26b345b3e1f9f90439e763c66d/1?pqorigsite $=$ gscholar $\& \mathrm{cbl}=44345$

Statistics Canada. (2017, November 29). Chart 3Percentage of women and men aged 25 to 34 with a bachelor's degree or higher', Canada, 2006 and 2016. Retrieved from https://www150.statcan.gc.ca/n1/daily-quotidien/171129/cg-a003-eng.htm

Staurowsky, J.E. (2019). The impact of Title IX and other equity laws on the business of women's sport. In N. Lough \& G.N. Andrea (Eds.), Routledge Handbook of the Business of Women's Sport (pp. 23-35). Routledge.

Stern, N.G., Gateley, A., \& Barrett, J.R. (2013). Is there perceived gender disparity for women practicing sports medicine? Advancing Women in Leadership, 33, 48-51. https://doi.org/10.18738/awl.v33i0.99

Tabachnick, B.G., Fidell, L.S., \& Ullman, J.B. (2007). Using multivariate statistics (5th ed.). Pearson.

Taylor, E.A., \& Wells, J.E. (2017). Institutionalized Barriers and Supports of Female Athletic Directors. Journal of Intercollegiate Sport, 10(2), 157-183. https://doi.org/10.1123.jis.2016-0041

The Sport Information Resource Centre: SIRC. (n.d.). Retrieved May 7, 2021, from https://www.sirc.ca

Torchia, M., Calabro, A., Gabaldon, P., \& Kanadli, S.B. (2018). Women directors contribution to organizational innovation: A behavioral approach. Scandinavian Journal of Management, 34(2), 215-224. https://doi.org/10.1016/j.scaman.2018.02.001

Vianden, J., \& Gregg, E.A. (2017). What's My Responsibility? Undergraduate heterosexual white men in sport management discuss increasing diversity in sport. Sport Management Education Journal, 11(2), 88-101. https://doi.org/10.1123/smej.2015-0023

Walker, N.A., \& Bopp, T. (2010). The underrepresentation of women in the male-dominated sport workplace: Perspectives of female coaches. Journal of Work Rights, 15(1), 47-64. https://doi.org/10.2190/WR.15.1.d

Weiner, J.M., \& Burton, L.J. (2016). The double bind for women: Exploring the gendered nature of turnaround leadership in a principal preparation program. Harvard Educational Review, 86(3), 339-365. https://doi:10.17763/1943-5045-86.3.339

Weyer, B. (2007). Twenty years later: Explaining the persistence of the glass ceiling for women leaders. Women in Management Review, 22(6), 482-496. https://doi.org/10.1108/09649420710778718

Whaley, D.E., \& Krane, V. (2012). Resilient excellence: Challenges faced by trailblazing women in U.S. sport psychology. Research Quarterly for Exercise \& Sport, 83(1), 65-76. https://doi.org/10.1080/02701367.2012.10599826

White, K. (2004). The leaking pipeline: Women postgraduate and early career researchers in Australia. Tertiary Education and Management, 10(3), 227-241. https://doi.org/10.1023/B:TEAM.0000044828.44536.67

Workplaces that Work for Women. (2020). Women in the workforce - Canada: Quick take. Retrieved May 7, 2021, from https://www.catalyst.org/research/women-in-the-workforce-canada/

Yang, Y., Chawla, N.V., \& Uzzi, B. (2019). A network's gender composition and communication pattern predict women's leadership success. Proceedings of the National Academy of Sciences, 116(6), 2033-2038. https://doi.org/10.1073/pnas.1721438116

Zheng, W., Surgevil, O., \& Kark, R. (2018). Dancing on the razor's edge: How top-level women leaders manage the paradoxical tensions between agency and communion. Sex Roles, 79(11-12), 633650. https://doi:10.1007/s11199-018-0908-6 